\title{
A Review of Smart Parking System based on Internet of Things
}

\author{
Harkiran Kaur ${ }^{1}$, Jyoteesh Malhotra ${ }^{2}$
}

\section{Accepted : 08/11/2018 Published: 31/12/2018}

\begin{abstract}
The Internet of Things expands the wireless paradigm to the edge of the network, which enables to develop a different kind of applications or services. By using IoT the application becomes more reliable, flexible or portable. It has a large amount of nodes on the various geographic positions, to increase the awareness of location or reduce the latency. There are numerous IoT applications like smart grid, smart hospital, smart industry, smart traffic management etc. In this paper, we describe the smart traffic management and parking system using the internet to control the chaos and also discuss the various researches on this concept.
\end{abstract}

Keywords: Bluetooth, Cloud Computing, Information Communication Technology (ICT), Internet of Things (IoT), Wireless Sensor Network (WSN)

\section{Introduction}

The use of IoT in the practical world become more relevant in the recent year by the rapid growth of technologies like mobile, embedded system, wireless system, cloud computing etc. Internet of Things helps to connect the living beings and the non-living things, which generates the communication between the virtual and non-virtual data. So, there are a large amount of data generated by the various number of nodes connected via the internet. After that, the relevant information should be converted from the pool of data. The WSN plays a very imperative role in the development of IoT. The concept of the smart city is the best suitable example for the integration of IoT and WSN with ICT. Smart City provides an advanced step for groundbreaking and cooperative amenities for all the social events such as healthcare, transportation, business etc. It uses IoT in an effective and secure manner to access the IP address of the object, and generate the communication link between the object and the system with the help of internet.

\section{Related Work}

IoT has a vital role in the traffic management in smart cities. Nowadays, many techniques like wireless sensor network, radio frequency, digital image processing based smart transportation system are introduced for traffic management. There are used to control the traffic in the more efficient way. In 2012, J. Yang uses GPS (Global Positioning system) and Android based application to provide the information related to the parking space. It has a better interface but it does not have the reservation feature [1].

M. Patil implements the WSN and RFID for the smart parking in 2013 [2]. In this system, the Inter-Integrated Circuit protocol is used according to that the car will guide the driver to find the path for parking by using RFID and WSN. This system is timeconsuming and expensive which are the major drawbacks. H.

${ }^{I}$ Department of Computer Science and Engineering, GNDU RC

Jalandhar, Punjab, India

${ }^{2}$ Department of Electrical and Computer Engineering, GNDU RC

Jalandhar, Punjab, India

*Corresponding Author: Email: Hksekhon92@gmail.com
Singh introduced the automated parking system with the help of Bluetooth access. In this system, the Bluetooth is used for the communication or network. This system is based on the rack and pinion mechanism for the linear motion. So the main drawback of this system is the whole parking is designed according to the rack and pinion mechanism which is quite expensive and timeconsuming [3].

According to Hilal Al-Khaurasi, the intelligent parking system was introduced which is based on image processing. In this paper, the concept of image processing is used. The sensor camera is used to capture the images which help to provide the results that are slots for parking are free or not. But, in term of visibility, the weather conditions like rain, fog, snow etc. may affect the system [4]. Another system is made by A.Sayeeraman in 2012. In this system, ZigBee is used to check the vacancy in the parking area. In this, the security feature is added i.e. exist password, without entering the password user cannot leave the parking. The gate will open when the user put the right exit password. The exit password is sent to the user at the entry time via SMS. The problem of this system is network congestion due to which user unable to receive the SMS. However, the use of SMS, GSM or ZigBee makes the system more expensive [5]. The other authors develop the parking reservation system by using the SMS. In this paper, the microcontroller is used which makes the system portable but the cost of implementation is very high because of the use of the microcontroller. The major problem is the system will crash if the workload on the microcontroller will increase[6].This [7] paper introduced the use of RFID, WSN, object ad-hoc network and information systems in which the traffic objects can be automatically tracked and controlled over a network. The concept of RFID is used as a new technology to reduce the installation cost and time [8].According to J. Sherly IoT-based transportation system is developed according to smart city view. The main aim of this paper is to develop the advanced and powerful communication between the technologies for the administration of the city and the citizens[9]. The raspberry pi 2 is used for the smart high defined picture. There are some ultrasonic sensors are used to detect the vehicle intensity and sends the signal to RASPBERRY PI 2 which controls the traffic problem [10].

Y K. Zang [11] designed an efficient decentralized framework for reducing the fuel consumption at any time of expedition or stoppage. This algorithm provides a solution for congestion 
Table 1. Current State-of-the-art

\begin{tabular}{|c|c|c|c|c|}
\hline $\begin{array}{l}\text { Sr. } \\
\text { No. }\end{array}$ & Paper Name & Description & Merits & Demerits \\
\hline 1. & $\begin{array}{l}\text { Smart Parking Services based on } \\
\text { Wireless Sensor Network[1]. }\end{array}$ & 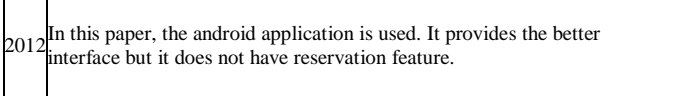 & $\begin{array}{l}\text { Usage of Android platform provides } \\
\text { better interface } \\
\text { Easy to use. }\end{array}$ & This system has not reservation feature. \\
\hline 2. & $\begin{array}{l}\text { Wireless Sensor Network and RFID for } \\
\text { the Smart Parking System[2]. }\end{array}$ & $\begin{array}{l}\text { In this paper, the RFID and the wireless sensors are used to make the } \\
2013 \text { Parking, according to this, it guide the driver to find the spot but this } \\
\text { system is time-consuming and expensive. }\end{array}$ & $\begin{array}{l}\text { It provides the slot information as } \\
\text { well as guides the driver. } \\
\text { It is compatible in existing parking. }\end{array}$ & $\begin{array}{l}\text { High cost } \\
\text { More time required for implementation. }\end{array}$ \\
\hline 3. & $\begin{array}{l}\text { Automated Parking System with } \\
\text { Bluetooth access[3]. }\end{array}$ & $\begin{array}{l}\text { In this system, the Bluetooth is used for the communication or network. } \\
\text { This system is based on the rack and pinion mechanism for the linear } \\
2014 \text { motion. So the main drawback of this system is the whole parking is } \\
\text { designed according to the rack and pinion mechanism which is quite } \\
\text { expensive and time-consuming. }\end{array}$ & $\begin{array}{l}\text { Bluetooth is used for registration or } \\
\text { identification. } \\
\text { Detect the unique registration number } \\
\text { if a new vehicle is parked. }\end{array}$ & $\begin{array}{l}\text { Cannot be used in the existing system. } \\
\text { Whole parking is to be designed. } \\
\text { Costly. } \\
\text { Time-consuming. }\end{array}$ \\
\hline 4. & $\begin{array}{l}\text { Intelligent Parking Management System } \\
\text { based on Image Processing[4]. }\end{array}$ & $\begin{array}{l}2014 \text { In this paper, the concept of image processing is used. The sensor camera } \\
\text { is used to capture the images which help to provide the results that are slots } \\
\text { for parking are free or not. But, in term of visibility, the weather conditions } \\
\text { like rain, fog, snow etc. may affect the system. }\end{array}$ & $\begin{array}{l}\text { Easily detect the presence of vehicles. } \\
\text { The camera is used as a sensor. }\end{array}$ & $\begin{array}{l}\text { Not compatible with some weather } \\
\text { conditions such as rain, fog etc. } \\
\text { Fixed position of the system. } \\
\text { GPS is not provided. }\end{array}$ \\
\hline 5. & $\begin{array}{l}\text { Zigbee and GSM based Secure Vehicle } \\
\text { parking management and reservation } \\
\text { system[5]. }\end{array}$ & $\begin{array}{l}2012 \begin{array}{l}\text { In this system, ZigBee is used to check the vacancy in the parking area. In } \\
\text { this, the security feature is added i.e. exist password, without entering the } \\
\text { put the right exit password. }\end{array}\end{array}$ & $\begin{array}{l}\text { Secure } \\
\text { Based on password system. } \\
\text { Use of GSM } \\
\text { Use of SMS }\end{array}$ & $\begin{array}{l}\text { Expensive. } \\
\text { The problem of this system is network } \\
\text { congestion due to which user unable to } \\
\text { receive the SMS. }\end{array}$ \\
\hline 6. & $\begin{array}{l}\text { Smart Parking Reservation System using } \\
\text { short message services (SMS) [6]. }\end{array}$ & 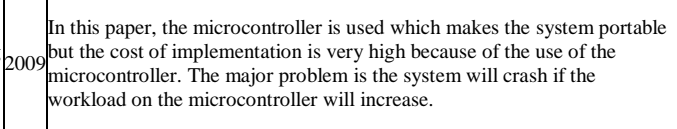 & $\begin{array}{l}\text { More } \\
\text { Secure. } \\
\text { Ease of usage. }\end{array}$ & $\begin{array}{l}\text { The cost of implementation is high. } \\
\text { GSM feature create bottlenecks } \\
\text { Overload of microcontroller leads to } \\
\text { system crash. }\end{array}$ \\
\hline 7. & $\begin{array}{l}\text { Intelligent Traffic Information System } \\
\text { Based on Integration of Internet of } \\
\text { Things and Agent Technology[7]. }\end{array}$ & $\begin{array}{l}\text { This paper introduced the use of RFID, WSN, object ad-hoc network and } \\
2015 \text { information systems in which the traffic objects can be automatically } \\
\text { tracked and controlled over a network. }\end{array}$ & $\begin{array}{l}\text { Provides tracking feature. } \\
\text { Use of WSN made this system more } \\
\text { reliable. }\end{array}$ & Networking congestion. \\
\hline 8. & Smart Traffic Management System[8]. & 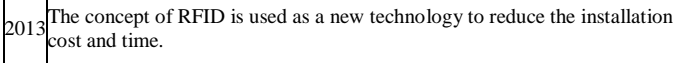 & Reduce the installation time and cost. & GPS is not used. \\
\hline 9. & $\begin{array}{l}\text { Internet of Things Based Smart } \\
\text { Transportation System[9]. }\end{array}$ & $2015 \mid \begin{array}{l}\text { In this paper, the IoT-based transportation system is developed according } \\
\text { to smart city view. The main aim of this paper is to develop the advanced } \\
\text { and powerful communication between the technologies for the } \\
\text { administration of the city and the citizens. }\end{array}$ & $\begin{array}{l}\text { Provide instant results. } \\
\text { Use for real-time traffic. }\end{array}$ & $\begin{array}{l}\text { The problem in data storage. } \\
\text { Use of image processing system. }\end{array}$ \\
\hline 10. & $\begin{array}{l}\text { Innovative Technology for Smart Roads } \\
\text { by using IoT devices[10]. }\end{array}$ & 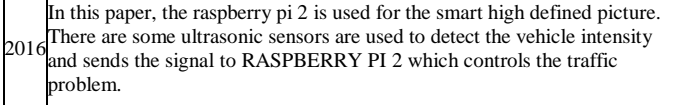 & $\begin{array}{l}\text { Automatically detect the vehicles. } \\
\text { Controls traffic related problems. }\end{array}$ & Expensive. \\
\hline 11. & $\begin{array}{l}\text { Optimal control and coordination of } \\
\text { connected and automated vehicles at } \\
\text { urban traffic intersections[11]. }\end{array}$ & \begin{tabular}{|l}
2016 An efficient decentralized framework for reducing the fuel consumption at \\
congestion control and helps to reduce the traveling time
\end{tabular} & $\begin{array}{l}\text { Efficient framework. } \\
\text { Solve congestion problem. } \\
\text { Reduce traveling time. }\end{array}$ & $\begin{array}{l}\text { Large time for implementation. } \\
\text { High cost. }\end{array}$ \\
\hline 12. & $\begin{array}{l}\text { Assessing the mobility and } \\
\text { environmental benefits of reservation- } \\
\text { based intelligent intersections using an } \\
\text { integrated simulator[12]. }\end{array}$ & $\begin{array}{l}\text { In this designed intersection control on reservation based system to take } \\
2012 \text { more advantage of extraordinary connectivity that provides dynamism to } \\
\text { connected transports }\end{array}$ & $\begin{array}{l}\text { Online reservation. } \\
\text { Dynamism connectivity of transports. }\end{array}$ & $\begin{array}{l}\text { The cost of reservation is high. } \\
\text { Network congestion. }\end{array}$ \\
\hline 13. & $\begin{array}{l}\text { Analysis of reservation algorithms for } \\
\text { cooperative planning at } \\
\text { intersections[13]. }\end{array}$ & $\begin{array}{l}\text { This represents the designed the fully automated car that has the major } \\
2010 \text { differences compared to nowadays. This paper also describes the } \\
\text { improvement of the reservation algorithm. }\end{array}$ & Based on reservation algorithm & Not practically implemented. \\
\hline 14. & $\begin{array}{l}\text { Analysis and modeled design of one } \\
\text { state-driven autonomous passing- } \\
\text { through algorithm for driverless vehicles } \\
\text { at intersections[14]. }\end{array}$ & $\begin{array}{l}2013 \text { In this paper, proposed the centralized scheduling algorithm i.e. } \\
\text { reservation-oriented. This ensures the high request to be answered as per } \\
\text { the preference. This algorithm is simulated on high priority vehicles }\end{array}$ & $\begin{array}{l}\text { Simulated on high priority vehicles. } \\
\text { Based on centralized scheduling } \\
\text { algorithm }\end{array}$ & $\begin{array}{l}\text { Complex } \\
\text { The difficulty of understanding. }\end{array}$ \\
\hline 15. & $\begin{array}{l}\text { Cloud-based Intelligent Transport } \\
\text { System[15]. }\end{array}$ & $2015 \mid \begin{array}{l}\text { This paper represent the multilayered vehicular data cloud platform which } \\
\text { was supported by IoT technologies and cloud computing }\end{array}$ & Support multiple technologies. & $\begin{array}{l}\text { The problem in data storage. } \\
\text { Hard to manage a large amount of data. }\end{array}$ \\
\hline 16. & $\begin{array}{l}\text { Visible light communication: } \\
\text { Application, architecture, } \\
\text { standardization and research } \\
\text { challenges[16]. }\end{array}$ & $\begin{array}{l}\text { In this paper, the unique computer code is designed that can communicate } \\
2016 \text { with various devices within the road. In this technological era, visible light } \\
\text { communication is also used for vehicle to vehicle communication. }\end{array}$ & $\begin{array}{l}\text { Strong communication between } \\
\text { machines to the machine. }\end{array}$ & $\begin{array}{l}\text { Consume a lot of time for } \\
\text { implementation. }\end{array}$ \\
\hline 17. & $\begin{array}{l}\text { Enabling Reliable and Secure IOT- } \\
\text { based Smart City Application[17]. }\end{array}$ & $2014 \begin{array}{l}\text { According to Elias Z. Tragos in this paper the IoT is used as the real-time } \\
\text { traffic monitor to reduce the overall traffic from the downtown area. }\end{array}$ & $\begin{array}{l}\text { Monitor real-time traffic. } \\
\text { Helps to reduce the overall traffic. }\end{array}$ & - \\
\hline 18. & $\begin{array}{l}\text { Smart City Architecture and its } \\
\text { Application based on IoT[18]. }\end{array}$ & $\begin{array}{l}2015 \begin{array}{l}\text { This paper mainly based on customized services for communication with } \\
\text { the help of Wi-Fi, WI-Max, Zig-Bee, Satellite Communication etc. to } \\
\text { convert the city into the smart city. For instance, we combine the health } \\
\text { related parameter of the driver while driving like pulse rate, blood pressure } \\
\text { etc. and provide the real-time health condition to the driver. This helps to } \\
\text { create the safer environment. }\end{array}\end{array}$ & $\begin{array}{l}\text { User-friendly. } \\
\text { Ease to communicate. } \\
\text { Measure all health related parameters. } \\
\text { Safer environment. }\end{array}$ & $\begin{array}{l}\text { Lots of sensors are used. } \\
\text { Required more time as compared to } \\
\text { another system. }\end{array}$ \\
\hline 19. & $\begin{array}{l}\text { Automatic Smart Parking System using } \\
\text { Internet of Things(IoT)[19]. }\end{array}$ & $\begin{array}{l}2015 \text { In this, the system designs a simple smart car parking system which is cost } \\
\text { system eco-friendly. }\end{array}$ & $\begin{array}{l}\text { Cost effective } \\
\text { Eco-friendly. }\end{array}$ & $\begin{array}{l}\text { Not solve the congestion related } \\
\text { problems. }\end{array}$ \\
\hline 20. & $\begin{array}{l}\text { Automatic Parking Management System } \\
\text { and Parking fee collection based on } \\
\text { number plate recognition[20]. }\end{array}$ & 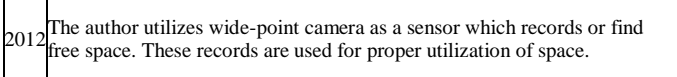 & Proper utilization of space. & $\begin{array}{l}\text { Use of camera makes the system } \\
\text { unreliable. }\end{array}$ \\
\hline
\end{tabular}


control and helps to reduce the traveling time. S. Huang[12] designed intersection control on the reservation based system to take more advantage of extraordinary connectivity that provides dynamism to connected transports. A. Fortella[13] represents the designed fully automated car that has the major differences compared to nowadays. This paper also describes the improvement of the reservation algorithm. The K.Zang [14] proposed the centralized scheduling algorithm i.e. reservationoriented. This ensures the high request to be answered as per the preference. This algorithm is simulated on high priority vehicles.

K. Ashokkumar [15] represent the multilayered vehicular data cloud platform which was supported by IoT technologies and cloud computing. In this paper, the unique computer code is designed that can communicate with various devices within the road. In this technological era, visible light communication is also used for vehicle to vehicle communication [16].According to Elias Z. Tragos [17] IoT is used as the real-time traffic monitor to reduce the overall traffic from the downtown area. [18] This paper mainly based on customized services for communication with the help of Wi-Fi, WI-Max, Zig-Bee, Satellite Communication etc. to convert the city into a smart city. For instance, we combine the health and transportation domain by this sensor can easily measure the all health related parameter of a driver while driving like pulse rate, blood pressure etc. and provide the real-time health condition to the driver. This helps to create the safer environment. Basavaraju [19] design a simple smart car parking system which is cost effective and also helps to decrease the carbon dioxide that makes this system eco-friendly. The author utilizes wide-point camera as a sensor which records or find free space and these records are used for proper utilization of space for the smart parking [20].

\section{Current State-of-the-art}

Based on literature survey done the following papers have been abstracted to find out the key merits and demerits.

\section{Open Issues and Challenges}

Nowadays, there are various challenges which are faced by today's driver as well as whole transportation system on daily basis likewise traffic congestion, parking system etc. To improve this transportation system, the following issues and factors are considered:

- Be able to sense vehicle accurately.

- Provide congestion free road.

- Manage a large amount of data.

- Enable to make smart decisions using real-time data.

- Reduce frustration and improve time-saving.

- Alleviate the problem related to pollution emission and fuel consumption.

\section{Conclusion}

Overall, in this paper, there are various types of methods or techniques are discussed. This review provides the gather information about the traffic management or smart parking methods which are used for the smart cities. The wide availability of sensors or wireless devices made the system more reliable or flexible and enables effective development of the IoT-based application. IoT provides enormous kind of solution for the traffic controlling and provide the vehicle to vehicle communication for the optimal result. This paper helps to understand all various methods of traffic management under the concept of the smart city.

\section{References}

[1] Yang Jihoon Jorge Portilla Teresa Riesgo, "Smart parking service based on wireless sensors Network," IEEE, 2012.

[2] ManjushaPatil Vasant N. Bhonge, "Wireless Sensor Network and RFID for Smart Parking System," Int. J. Emerg. Technol. Adv Eng. Website www.ijetae.com, vol. 3, no. 4, 2013.

[3] Harmeet Singh ChetanAnand Vinay Kumar Ankit Sharma, “Automated Parking System With Bluetooth Access," Int. J. Eng. Comput. Sci. ISSN2319-7242, vol. 3, no. 5, pp. 5773-5775.

[4] H. A.-K. I. Al-Bahadly, "Intelligent Parking Management System Based on Image Processing," J. Eng. Technol., vol. 2, pp. 55-67, 2014.

[5] AshwinSayeeraman P.S.Ramesh, "ZigBee and GSM based secure vehicle parking management and reservation system," J. Theor. Appl. Inf. Technol., vol. 37, 2012.

[6] HanitaDaud Noor HazrinHanyMohamadHanif Mohd Hafiz Badiozaman, "Smart parking reservation system using short message services (SMS)," IEEE, 2009.

[7] H. O. Al-Sakran, "Intelligent Traffic Information System Based on Integration of Internet of Things and Agent Technology," Int. J. Adv. computer Sci. Appl., vol. 6, no. 2, 2015.

[8] N. Lanke, "Smart Traffic Management System," Int. J. Comput. Appl., vol. 75, no. 7 .

[9] J. Sherly D. Sonasundareswari, "Internet of Thing Based Smart Transport System," Int. J. Eng. Technol., vol. 75, no. 7, 2013.

[10] Sheela.S, "Innovative Technology for Smart Roads by Using IOT Devices,” Int. J. Innov. Res. Sci. Eng. Technol., vol. 5, no. 10.

[11] Y. J. Zhang or A. A. Malikopoulos and C. G. Cassandras, "Optimal control and coordination of connected and automated vehicles a urban traffic intersections," in Proc. Amer. Control Conference[online], 2016.

[12] S. Huang or A. W. Sadek and Y. Zhao, "Assessing the mobility and environmental benefits of reservation-based intelligent intersections using an integrated simulator," IEEE Trans. Intell. Transp. Syst., vol. 13, 2012.

[13] A. d. La Fortelle, "Analysis of reservation algorithms for cooperative planning at intersections," in Proceding. 13th International IEEE Conference Intelligent Transport System, 2010.

[14] K. Zhang A. de La Fortelle D. Zhang and X. Wu, "Analysis and modeled design of one state-driven autonomous passing-through algorithm for driverless vehicles at intersections," in Proc. IEEE 16th Int. Conf. Comput.Sci. Eng, 2013.

[15] K. Ashokkumar, "CLOUD BASED INTELLIGENT TRANSPORT SYSTEM,” Sci. Direct, vol. 50, pp. 58-63, 2015.

[16] L. U. Khan, "Visible light communication: Application, architecture, standardization, and research challenges.," Digit. Commun. Networks, Elsevier, pp. 1-10, 2016.

[17] E. Z.Tragos, "Enabling Reliable and Secure IOT- based Smart City Application," IEEE, pp. 111-116, 2014.

[18] G. Aditya, S. Bryan, P. Gerard, and M. Sally, "Smart City Architecture and its Application based on IoT," Sci. Direct, Elsevier, vol. 52, pp. 1089-1094, 2015.

[19] S. R. Basavaraju, "Automatic Smart Parking System using Internet of Things(IoT),” Int. J. Sci. Res. Publ., vol. 5, no. 12, pp. 629-632, 2015.

[20] R. M.M, A.Musa, AtaurRahman, N.Farahana, and A.Farahana, "Automatic Parking Management System and Parking fee collection based on number plate recognition," Int. Mach. Learn. Comput., vol. 2, 2012. 